\title{
Erratum to: Enhanced biosurfactant production through cloning of three genes and role of esterase in biosurfactant release
}

\author{
Kamaljeet Kaur Sekhon ${ }^{{ }^{*}}$, Sunil Khanna ${ }^{2}$ and Swaranjit Singh Cameotra ${ }^{3}$
}

\section{Erratum to: Microbial Cell Factories 2011, 10:49 DOI 10.1186/1475-2859-10-49}

The authors wish to publish an erratum to address concerns that were raised by one of the readers of their article [1].

Post publication peer review by the journal found that surfactin or esterase production could not have occurred as described in the article because the recombinant Escherichia coli strains do not possess all the DNA sequences required for their production. Moreover, the regions that were used for the nucleotide sequence alignment of biosurfactant biosynthesis and esterase genes do not show any significant amino acid sequence similarity, which undermines the conclusions about the homology of these genes.

The authors provided the following explanation:

1. The authors do not claim that the biosurfactants produced by Bacillus subtilis SK320 and its recombinants are "surfactin"- the biosurfactants reported here belong to the class of lipopeptides having excellent emulsifying properties as stated clearly in "Conclusions" section. If any statement in the article is implying that the biosurfactants produced by Bacillus subtilis SK320 are "surfactin", it should be considered as an error.

2. The primers used to amplify the Bacillus subtilis SK320 genomic DNA are named or designated randomly. It should not be understood from the designation that only a particular gene or gene sequence was targeted or amplified using that particular primer. As it is an error made accidently, the authors would like to rename the primers as $\mathrm{Pa}, \mathrm{Pb}$ and $\mathrm{Pc}$ instead of sfp, sfp0 and srfA (Table 1). The article does not suggest anywhere that the biosurfactant production can happen only in the presence of one gene, it requires the entire operon and so was the objective of each primer.

3. The authors would like to emphasize that "There was no apparent biosurfactant and esterase activity found in the parent $E$. coli $\mathrm{DH} 5 \alpha$ strain, whereas the recombinant strains were able to utilize olive oil as a carbon source" (statement cited from section: "Cloning and expression of biosurfactant genes" under "Results and Discussion"). Since the recombinant E. coli strains were able to utilize olive oil as a carbon source, it was the first step towards claiming the successful cloning of the biosurfactant genes.

4. The authors encourage the readers to refer to the GenBank accession numbers of the gene sequences submitted to NCBI's nucleotide database given in the article and make their own alignments and do comparisons for studying the homology of these genes.

Table 1 Gene specific primers used for amplification of chromosomal DNA of Bacillus subtilis SK320

\begin{tabular}{lll}
\hline Primers & Primer sequence 5'-3' & $\begin{array}{l}\text { Recombinants } \\
\text { (designation) }\end{array}$ \\
\hline $\mathrm{Pa}$ & 5'-CGTTCGCTCAGTCATAAGCA-3' & BioS a \\
& 5'-CCTGTATGCACACCCATCTG-3' & \\
$\mathrm{Pb}$ & 5'-CTAGAATTCAGATTTACGGATTTATATG-3' & BioS b \\
& 5'-GGGGAATTCAGGGTGTGCGGCGCATAC-3' & \\
$\mathrm{PC}$ & 5'-TCCGTTTTTCCTTGTTCACC-3' & BioS C \\
& 5'-TCTTTCTGCCACTGCATCAC-3' & \\
\hline
\end{tabular}

*Correspondence: kamalsekhon80@yahoo.com

${ }^{1}$ Department of Biotechnology and Environmental Sciences, Thapar

University, Patiala, Punjab 147001, India

Full list of author information is available at the end of the article
C The Author(s) 2017. This article is distributed under the terms of the Creative Commons Attribution 4.0 International License (http://creativecommons.org/licenses/by/4.0/), which permits unrestricted use, distribution, and reproduction in any medium, provided you give appropriate credit to the original author(s) and the source, provide a link to the Creative Commons license, and indicate if changes were made. The Creative Commons Public Domain Dedication waiver (http://creativecommons.org/ publicdomain/zero/1.0/) applies to the data made available in this article, unless otherwise stated. 


\section{Author details}

${ }^{1}$ Department of Biotechnology and Environmental Sciences, Thapar University, Patiala, Punjab 147001, India. ${ }^{2}$ NIIT University, Neemrana, Rajasthan 301705, India. ${ }^{3}$ 104, 10A, Chandigarh 160036, India.

The online version of the original article can be found under doi:10.1186/1475-2859-10-49.

\section{Publisher's Note}

Springer Nature remains neutral with regard to jurisdictional claims in published maps and institutional affiliations.
Received: 14 August 2017 Accepted: 14 August 2017

Published online: 22 August 2017

\section{Reference}

1. Sekhon KK, Khanna S, Cameotra SS. Enhanced biosurfactant production through cloning of three genes and role of esterase in biosurfactant release. Microb Cell Fact. 2011:10:49. doi:10.1186/1475-2859-10-49.
Submit your next manuscript to BioMed Central and we will help you at every step:

- We accept pre-submission inquiries

- Our selector tool helps you to find the most relevant journal

- We provide round the clock customer support

- Convenient online submission

- Thorough peer review

- Inclusion in PubMed and all major indexing services

- Maximum visibility for your research

Submit your manuscript at www.biomedcentral com/submit 